\title{
Utilization of Powerful Words in Compiling Effective Communication Materials
}

\author{
Moh. Zainudin ${ }^{(1)}$, Asef Wildan Munfadlila(2), Saptono Hadi ${ }^{(3)}$ \\ (1),(2) Stikes Bina Sehat PPNI Mojokerto, Indonesia \\ ${ }^{(3)}$ Universitas Nahdlatul Ulama Blitar, Indonesia \\ E-mail: ${ }^{(1)}$ zenika59@gmail.com, ${ }^{(2)}$ acheif90@gmail.com, ${ }^{(3)}$ saptono656@gmail.com
}

Received: 15 December 2020; Revised: 22 April 2021; Accepted: 5 May 2021

\begin{abstract}
In the Indonesian language course, communication can be included in the area of language skills, namely speaking and writing. To carry out effective communication, there are four stages that must be carried out, namely fact finding, planning, communicating, and evaluation. The purpose of this research is to describe the concept map of effective communication material based on powerful words. This research method uses qualitative research methods with data sources in the form of books by Erwin Parengkuan et al. entitled Talk-inc Points published by Gramedia Pustaka Utama, Trianto's book entitled Designing an innovative-progressive learning model published by KencanaPrenada Media Group, and and a book by Cutlip, Scoot M., Allen H. Center, and Glen M. Broom in 2011 entitled. Effective Public Relations, Ninth Edition published by Kencana. The data collection technique used by the researcher was document study by collecting documents related to the preparation of material, effective communication material and powerful words material. The data analysis carried out by researchers is as follows: (1) data reduction (2) displaying data by compiling relevant data, (3) drawing conclusions to get a meaning that scattered symptoms have deep meaning. The results of this study indicate that the use of powerful words in the preparation of effective communication materials produces a concept map for effective communication materials. Making a concept map for effective communication material becomes easier to learn and understand, that in effective communication there are four stages that must be done, namely fact finding, planning, communicating, and evaluation.
\end{abstract}

Keywords: effective communication; material preparation; powerful words

\section{INTRODUCTION}

As social beings, humans cannot be separated from communication. As a form of interaction that affects each other, communication is not limited to the use of verbal language but also facial expressions, paintings, art and technology (Shannon, 1997). This is in accordance with his opinion (Chaer, 2009) that the agreed verbal and nonverbal symbols, which like, are an effective means of communication to express ideas and feelings.
In the Indonesian language course, communication can be included in the area of language skills, namely speaking and writing. Both of these language skills are productive skills (Tarigan, 2008). In studying Indonesian language courses, both nursing and midwifery students are required to master four language skills, namely reading, writing, listening, and speaking. Mastery of these four skills is certainly very helpful for students in helping patients heal, both when students are doing an internship at 
the hospital, or when they graduate and work in the hospital.

Effective communication suggests the integrity of the message received by the communicant as well as the integrity of the message conveyed by the communicator. In other words, there is no difference between the communicator and the communicant about the messages in the communication process. Of course it is not easy to make effective communication. Required conditions must be met in order to communicate effectively. There are four stages that must be done so that communication can run effectively, namely fact finding, planning, communicating, and evaluation. First, fact finding suggests the need to find facts and data about the communicant regarding his wishes and composition. Second, planning suggests plans about what to say and how to put it forward based on the facts and data obtained. Third, communicating suggests the suitability of communication carried out with the planning that has been compiled. At this point, we must pay attention to the factors that influence communication, namely the credibility of the message giver, the content of the message, the suitability of the message content, consistency, channels, and the capabilities of the communicant. Fourth, evaluation suggests assessment and analysis to see how the communication results (Scoot M. Cutlip, Allen H. Center, 2011).

Furthermore, powerful words are the power of words. The use of powerful words in communicating effectively can help emphasize the message to make it more memorable and make an impression on the communicant's memory. To achieve powerful words, there are at least four key words, namely 1) know what is being said and to whom it is speaking. This point suggests knowledge of the listener's needs, 2) very personal. Capable of capturing the hearts of listeners by positioning themselves as people who have known listeners for a long time. Position yourself as a friend who cares about his best friend. 3) sincere. Sincerity is the key to a powerful word. To be able to achieve sincerity, there are two key words that a speaker must do, namely speaking in accordance with facts and speaking honestly, without making up. 4) logical (makes sense). The key word for this point is that the speaker's thoughts must be in line with the listener's thoughts (Parengkuan, 2009).

Furthermore, so that effective communication material can be understood easily, it is necessary to make a concept map to make it easier for students to follow the flow of the material. Referring to the 4-D development model Thiagarajan, Semmel and Semmel, 1974(Trianto, 2012), a concept map is the result of identifying the main concepts being taught and arranging them systematically. Linking one concept with other relevant concepts, thus forming a concept map.

Research on effective communication has been carried out by many previous researchers, including the following.

First, a research entitled effective communication in the world of education written by YossitaWisman. The result of this research is that the appropriate method in educational communication is direct or indirect communication, adapted to the situation and conditions (Wisman, 2017).

Second, a study entitled The Effect of Effective Communication Training to Increase Student Self-Efficacy written by DetaShinta Kusuma Wardani. The result of this study is that effective communication training has a great effect on increasing student self-efficacy (Wardani, 2012).

Third, a study entitled The Effect of Effective Communication to Improve Student Learning Outcomes written by Hugo Aris Suprapto. The results of this study are the use of using effective communication has a significant effect on increasing learning outcomes 95\%.(Suprapto, 2018).

Based on the results of research conducted by previous researchers, it can be explained that there are positive results from research on effective communication. In connection with this study, there are differences in research conducted by researchers with previous researchers, namely the preparation of effective communication materials based on powerful words, which has never been done by previous researchers. So that the purpose of this study can be formulated, namely to describe the concept map of effective communication materials based on powerful words.

\section{MATERIALS AND METHODS}

This study uses qualitative research methods, namely research methods that produce data in the form of written or spoken words from peo- 
ple or observable behavior(Moleong, 2008). Some say that between qualitative and quantitative research, there are differences in data. Data in qualitative research can be in the form of personal documents, field notes, respondent's words and actions, documents, etc., while quantitative research data is in the form of numbers. (Sugiyono, 2013).

Furthermore, the source of data in this study is a book by Erwin Parengkuan et al. entitled Talk-inc Points published by Gramedia Pustaka Utama and Trianto's book entitled Designing an innovative-progressive learning model published by KencanaPrenada Media Group, and a book by Cutlip, Scoot M., Allen H. Center, and Glen M. Broom in 2011 entitled. Effective Public Relations, Ninth Edition published by Kencana.

The data in this study are the words, sentences or paragraphs in the three books, namely the material on how to arrange the material which is realized with concept maps and material on effective communication and powerful words.
The data collection technique used by the researcher was document study by collecting documents related to the preparation of material, effective communication material and powerful words material.

The final part, is the data analysis technique. Data analysis carried out by researchers is as follows: (1) data reduction. This activity includes selecting data on the basis of its level of relevance and relation to the data set, compiling the data in similar units, and coding. (2) displaying data by compiling relevant data, (3) drawing conclusions to get a meaning that scattered symptoms have deep meaning.

\section{RESULT AND DISCUSSION}

In this section, displays the results of the preparation of effective communication materials based on powerful words, which in the formulation produces a concept map for effective communication materials. This can be seen in Figure 1.

Figure 1 shows that there are four discussions in effective communication, namely fact finding,

Figure 1. four discussions in effective communication

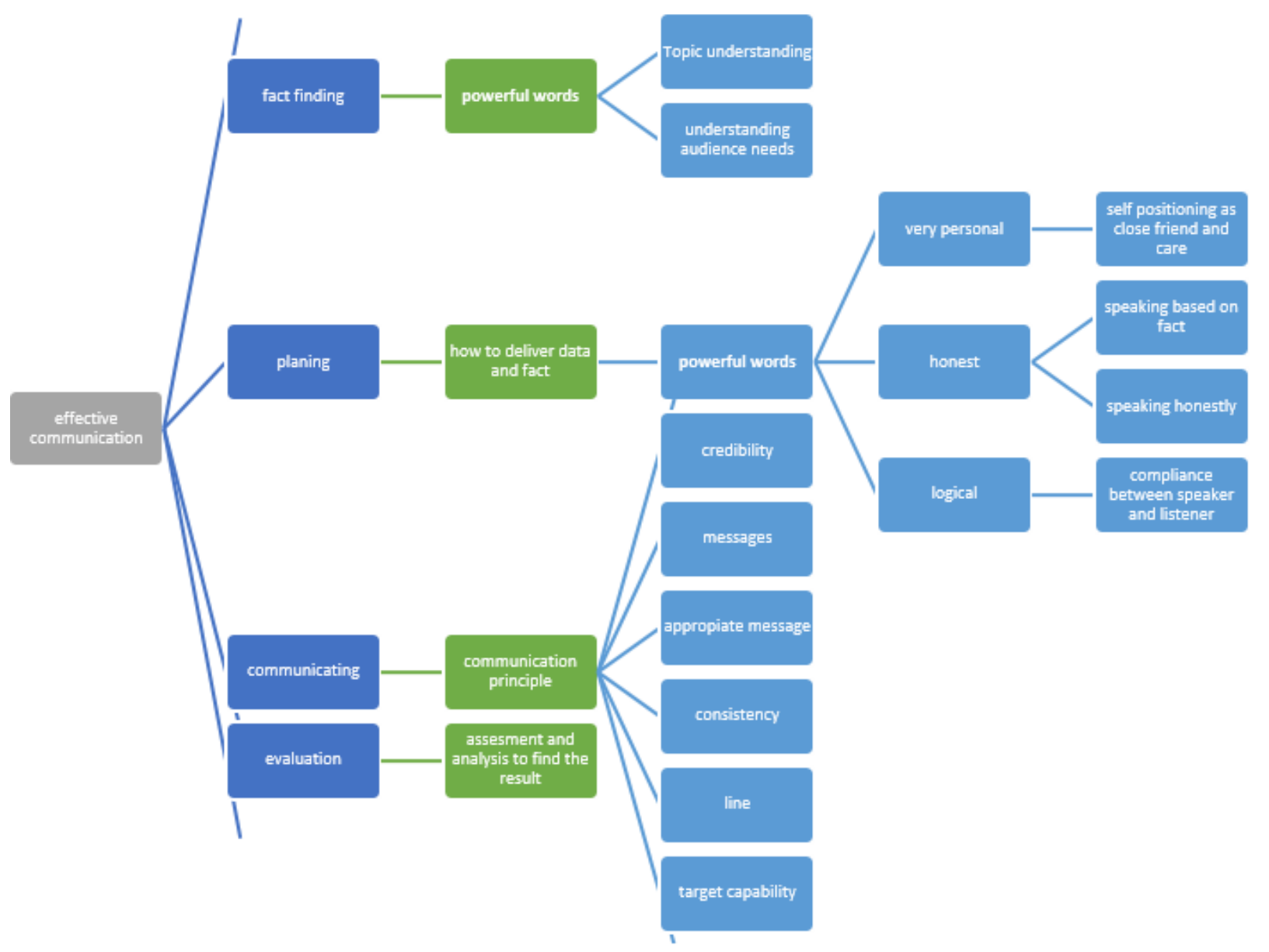


planning, communicating, and evaluation.

First, fact finding suggests the need to find facts and data about the communicant regarding his wishes and composition. In this section, powerful words can be included, because they suggest knowledge of the topic and the needs of the listener. Knowledge of the topic is very necessary because by knowing and mastering the topic well, the speaker will not lose direction in communicating so that he is always focused. Likewise with knowledge about the needs of listeners. This activity really helps the speaker in forging a very close relationship so that the communicator and the communicant care and accept each other.

Second, planning suggests plans about what to say and how to put it forward based on the facts and data obtained. In this section, powerful words can be included because they suggest that the relationship that must be made between the speaker and the listener is very personal. This means that it is as if the speaker has known the listener for a long time and shows a sense of care. Next is sincere. There are two key words for achieving sincerity, namely speaking according to facts and speaking with honesty. Then it is logical or it makes sense that what is conveyed by the communicator is in line with the thoughts of the communicant. This is very important because if it is not in line between the thoughts of the communicator and the communicant, the message will not be able to arrive and be well received.

Third, communicating suggests the suitability of communication carried out with the planning that has been compiled. At this point, we must pay attention to the factors that influence communication, namely the credibility of the message giver, the content of the message, the suitability of the message content, consistency, channels, and the capabilities of the communicant.

Fourth, evaluation suggests assessment and analysis to see how the communication results. This is useful to see whether all messages have been well received by the communicant. Are there any obstacles in the communication process, both from within and from outside.

\section{CONCLUSION}

Based on the results and discussion, it can be concluded that the use of powerful words in the preparation of effective communication materials produces a concept map for effective communication materials. Making a concept map for effective communication material becomes easier to learn and understand, that in effective communication there are four stages that must be done, namely fact finding, planning, communicating, and evaluation. The use of powerful words in the effective communication stage can be included in the fact finding and planning stage, where the components of powerful words include knowledge of topics and listener needs, while at the planning stage, powerful words that can be entered to reveal data and facts are 1) very personal ,2) sincere, and 3) logical. Furthermore, the recommendation of the research is applied to real learning in the classroom to determine the results of effective communication according to the stages and to determine the effect of using powerful words in supporting effective communication activities.

\section{REFERENCES}

Chaer, A. (2009). Linguistik Umum. Jakarta: Rineka Cipta.

Moleong, L. J. (2008). Metodologi Penelitian Kualitatif. Bandung: Remaja Rosda Karya.

Parengkuan, E. (2009). Powerful Words: Teknik Menyihir Hadirin Lewat Kekuatan KataKata. In Talk-inc. Points: Kekuatan Mental, Ketepatan Kata, dan Totalitas Bahasa Tubuh untuk menjadi Pembicara Profesional (pp. 124-128). Jakarta: Gramedia Pustaka Utama.

Scoot M. Cutlip, Allen H. Center, dan G. M. B. (2011). Effective Public Relations (9th ed.). Kencana.

Shannon, C. E. (1997). The Mathematical Theory of Communication. M.D. Computing. https://doi.org/10.2307/410457

Sugiyono. (2013). Memahami Penelitian Kualitatif. Bandung: Alfabeta.

Suprapto, H. A. (2018). Pengaruh Komunikasi Efektif untuk Meningkatkan Hasil Belajar Kewirausahaan Mahasiswa. Lectura : Jurnal Pendidikan, 9(1), 1-9. https:// doi.org/10.31849/lectura.v9i1.913

Tarigan, H. G. (2008). Berbicara sebagai suatu Keterampilan Berbahasa. Bandung: Angkasa. 